\title{
La ciudad literaria: entre el registro oficial y la experiencia individual ${ }^{1}$
}

\author{
Orfa Kelita Vanegas Vásquez ${ }^{2}$ \\ Universidad del Tolima (Colombia) \\ ORCID: 0000-0002-3455-6563 \\ Recibido: 10 de enero de 2019 \\ Aceptado: 10 de febrero de 2019
}

\section{Resumen}

Este estudio, a partir del conjunto de narrativas colombianas de reciente publicación, explora la ciudad literaria desde la percepción subjetiva de quien la vive y la nombra. La escritura establece coordenadas espaciales y reubica plazas, calles, monumentos $\mathrm{y}$ edificios gubernativos en correlación con el universo anímico de quien los transita y habita. Los lugares urbanos solo existen a través de la conciencia que de ellos tiene quien narra, un gesto decisivo porque ubica el espacio ficcional como elemento vivo, intrínseco a la existencia del personaje, parte del yo narrado, de la vida íntima y la memoria personal. La búsqueda de razones para explicar el inconformismo anímico con el presente va unida al seguimiento de los lugares perdidos. La ciudad y su cambiante nomenclatura es un "estado de ánimo", que resignifica el

\section{Abstract}

This study, from the set of recently published Colombian narratives, explores the literary city from the subjective perception of those who live and name it. The writing establishes spatial coordinates and relocates squares, monuments, government buildings in correlation with the psychic universe of who transits and inhabits them. The urban places only exist through the awareness of those who narrate them, a decisive gesture because it places the fictional space as a living element, intrinsic to the existence of the hero, part of the narrated self, of intimate life and personal memory. The search for reasons to explain the psychic nonconformity with the present goes together with the follow up of lost places. The city and its changing nomenclature is a "state of mind", that resignifies the past of the nation and confront the modernist

1 The literary city: between official history and personal memory

2 Dra. en Letras por la Universidad Nacional de Cuyo, Argentina. Profesora Asociada de la Universidad del Tolima, Colombia. okvanegasv@ut.edu.co. 
pasado de la nación y confronta los paradigmas modernistas de lo urbano, como estancia de orden, seguridad y progreso.

Palabras claves: ciudad textual, narrativa colombiana, memoria, emociones. paradigms of the urban, as a stay of order, security and progress.

Este estudio deriva de un proyecto de investigación más amplio, que considera lo emocional traumático: el miedo, la desesperanza, el resentimiento, etc., como fuerza protagónica de los elementos ficcionales en una serie de narrativas colombianas de reciente publicación ${ }^{3}$. En esta ocasión, se intenta demostrar que las imágenes simbólicas del pasado nacional van circunscritas a la memoria afectiva que los personajes tienen de la ciudad transitada. Los lugares recordados se establecen en la escritura como núcleos no solo de una historia oficial sino, y especialmente, de una historia individual. La ciudad literaria es, por tanto, resultado de la captación anímica, se levanta del entramado de simbologías, relatos e imágenes que conforman el lado no material del espacio urbano. En la vivencia espiritual y material de la urbe los personajes exteriorizan la realidad intangible, que aqueja al sujeto contemporáneo en ciudades asediadas por la violencia desmesurada.

\section{Cartografías urbanas de la incertidumbre}

El "sentimiento de inseguridad" es quizás uno de los fenómenos que define con cercana exactitud la existencia del sujeto contemporáneo. Para Guglielmo Ferrero (2013), la relación entre dirigentes y ciudadanos está constreñida por el recelo y la desconfianza, situación que produce una sensación de inseguridad y afecta hasta los espacios más íntimos. El temor al poder político vuelve recelosos a hombres y mujeres ante las medidas que el gobernante propone, y, a su vez, el gobernante, al someter a su normativa al pueblo, teme siempre a que este proceda contra él (p. 40). Esta situación, en efecto, no se reduce a la relación de poder entre gobernantes y gobernados, sino que también determina el trato entre los gobernados, es decir, entre los mismos ciudadanos y los espacios que habitan. Si el sentimiento de inseguridad surge de fuerzas enfrentadas, los espacios urbanos, con sus diferentes frentes de poder, son, igualmente, fuente fecunda de emociones de angustia y zozobra. Toda comunidad resguarda en su seno el miedo a un enemigo, que puede materializarse en la figura del sicario, por ejemplo, o en fenómenos como el narcotráfico, la de- 
lincuencia, la drogadicción. Las sociedades contemporáneas sienten la amenaza continua de un adversario que toma forma en el orden caprichoso y jerárquico de los sujetos que se desplazan por el espacio urbano. Sentimos pender sobre nuestras cabezas la espada del destrozo. En la ciudad moderna se sufre, según Delumeau (2002), del "Complejo de Damocles".

Las ciudades no son solo fenómenos físicos, formas de ocupar el territorio o tipos de aglomeración, son, también, espacios donde los fenómenos de expresión entran en contacto con la racionalización y lo emocional con el objeto de sistematizar la vida social (Canclini, 1998). Las prácticas del espacio trazan las condiciones determinantes de la vida comunitaria; el territorio urbano adquiere volumen en la medida en que se va colmando de las experiencias de vida de quien lo habita (Heffes, 2013). De esta manera, la interpelación de lo íntimo a partir de la caracterización de determinados lugares, y viceversa, abre otra posibilidad de indagar los complejos mecanismos que diseñan el arco de tensiones entre ciudad practicada, ciudad memorada y ciudad del discurso oficial.

Se reconoce que la ciudad en la literatura se ha identificado por ser el territorio donde se va tramando la progresiva identificación de los personajes con los sitios que habitan, donde se van localizando los referentes propios y ajenos que fundan el espacio personal (Aínsa, 2006: 166-169). La narrativa es sitio privilegiado para imaginar la ciudad vivida, asimismo para resemantizarla como lenguaje que traduce los cambios de imaginario de lo urbano y su relación con los ritmos económicos y políticos contemporáneos. Desde finales de la década del setenta, los autores colombianos ofrecen deslindes y rupturas con respecto a los modos tradicionales de la generación anterior -García Márquez y novelistas incluidos en el "boom" narrativo-, en cuanto a la representación de lo citadino en la ficción. La inclinación a lo rural y lo regionalista dio lugar a nuevas formas de expresión literaria de los espacios urbanos (Giraldo, 2011). La proliferación actual de la "literatura urbana", considera Locane (2016), responde a la lucha por el "derecho a la ciudad", que, en términos de Lefebvre (1968), es el poder colectivo de dar forma al espacio urbano de acuerdo con necesidades e intereses específicos y diversos. En concordancia, en las últimas décadas, la urbe en la ficción no cumple una función secundaria, de mero escenario, sino que ella misma es figura central de las operaciones de escritura.

Es necesario aclarar desde estas primeras líneas, que las narrativas que abordaremos más adelante no son parte de lo que la crítica colombiana ha denominado "literatura urbana" (Pineda Botero, 1990, 
1995; Jaramillo, Giraldo, 2001; Mejía Correa, 2010; Valencia, 2010; Figueroa, 2010), es decir, textos que disponen de recursos específicos para dar a la ciudad el papel protagónico, reflexionar sobre ella y reconstruirla. Las narraciones de este artículo, si bien ubican los espacios urbanos como elemento irreductible del relato, no son específicamente urbanas ni "literatura de ciudad". Los lugares citadinos que analizamos toman significación en función del devenir y la memoria de los narradores. La experiencia del espacio urbano proyecta un retrato polivalente de la ciudad como sitio donde anida el recuerdo traumático y se posiciona una voz crítica, que debate los modos de acción y participación de la sociedad y las fuerzas gubernativas en la construcción de ideales políticos, de identidad, nación e historia.

La visión de mundo y texto, y la idiosincrasia de estilo de los escritores nacionales, según Giraldo (2011), dejan ver que la ciudad ha sido un "verdadero caleidoscopio, un mosaico de territorios y de perspectivas: externos, internos, culturales sociológicos, políticos, históricos" (p. 108). Si esto es así, las consecuencias de la violencia sociopolítica van ligadas a la construcción y ampliación de las ciudades colombianas. Por ejemplo, el desplazamiento y la migración son factores decisivos en la modificación de los espacios urbanos. El paso de provinciana a cosmopolita de la ciudad colombiana, podría leerse en las maneras como la literatura representa los fenómenos migratorios:

Cuando se habla de ciudades recreadas, formuladas o narradas, se encuentran referencias y connotaciones diversificadas: no todos las habitan de la misma manera, ya que no son espacios construidos y poblados, sino cuerpos complejos con diversas posibilidades de experiencia o de vivencia. Cada ciudad es un cuerpo que va más allá de los límites geográficos y demográficos (Giraldo, 2011: 110).

Las narrativas en cuestión coinciden en significar el paisaje urbano como un "cuerpo", que se constituye no desde el afuera sino desde un adentro subjetivo, desde la naturaleza íntima de los protagonistas. La dimensión ontológica de lo citadino integra la dimensión topológica, como parte de una comunicación y tránsito naturales del exterior al interior y viceversa (Aínsa, 2006: 172). Las calles, plazas, edificios, emergen del estado emocional de quien cuenta. Por lo tanto, la "ciudad textual" se constituye en relación con la faceta afectiva del personaje que la narra, es producto del miedo y del sentimiento de desolación.

Si bien las letras colombianas han recreado diversas ciudades del país -Cali, Medellín, Cartagena, Pasto, La Guajira-, Bogotá, como ciudad capital, predomina en el paisaje narrativo. El carácter disímil con 
que los autores la identifican o definen es indicativo de la complejidad de su realidad. Glosando la idea de Ítalo Calvino (1985), Bogotá, en la escritura, sería una de esas ciudades diversas que se suceden sobre el mismo suelo y bajo el mismo nombre (p. 18). A tenor de la vertiginosidad con que ocurre la vida de la nación, las metáforas de Bogotá "han sido inquietantes y extremas en los últimos años, pues se dan simultáneamente el afán dereconstruirla en determinados momentos históricos, y la afirmación de un inmediato presente caótico, apocalíptico, tenebroso o desencantado" (Giraldo, 2011: 118).

Para Martín-Barbero (2009), Bogotá es un "laberinto del miedo"; la mutación abrupta de su territorio despierta en el transeúnte recelo e incertidumbre. Esta ciudad se impone con un "orden temerario", que socava silenciosamente la intimidad del habitante y hace temer los lugares recorridos cotidianamente. El devenir capitalino se construye con la incertidumbre que produce el otro, con la desconfianza hacia el que pasa a nuestro lado, en la calle. Proyectar a Bogotá como "laberinto del miedo", consideramos, "espacializa" los afectos, da territorio al cúmulo de emociones asociadas a la sensación de inseguridad y desconfianza. Los espacios urbanos coligados a lo emocional constituyen un simbolismo de las emociones, las hace menos ubicuas y abstractas.

La Bogotá de la década de los ochenta y los noventa es motivo de escritura en El ruido de las cosas al caer (2011), de Juan Gabriel Vásquez. La realidad lacerante de una ciudad asediada por el narcoterrorismo se va urdiendo en la tensión entre el acontecer cotidiano del protagonista y los sitios que transita. Recuérdese que la novela de Vásquez narra el estado de miedo y desamparo del narrador, Antonio Yammara, a causa de un tiro recibido en un atentado homicida dirigido a otra persona. La evocación de este suceso, catorce años después, es lo que desencadena los hechos y posibilita un espacio para la representación de la Bogotá de los noventa. Una "ciudad gris", con un "cielo gris" (Vásquez, 2011: 107), que se instala en el relato como recuerdo lacerante del terror desatado contra la población:

Por esos días mi ciudad comenzaba a desprenderse de los años más violentos de su historia reciente. No hablo de la violencia de cuchilladas baratas y tiros perdidos, de cuentas que se saldan entre traficantes de poca monta, sino la que trasciende los pequeños resentimientos y las pequeñas venganzas de la gente pequeña, la violencia cuyos actores son colectivos y se escriben con mayúscula: el Estado, el Cartel, el Ejército, el Frente. Los bogotanos nos habíamos acostumbrado a ella, en parte porque sus imágenes nos 
llegaban con portentosa regularidad desde los noticieros y los periódicos; ese día, las imágenes del más reciente atentado habían empezado a entrar, en forma de boletín de última hora, por la pantalla del televisor [...] vimos, encima de las fechas de su nacimiento y de su muerte todavía fresca, la cara en blanco y negro de la víctima. Era el político conservador Álvaro Gómez [...] Nadie preguntó por qué lo habrían matado, ni quién, porque esas preguntas habían dejado de tener sentido en mi ciudad, o se hacían de manera retórica, sin esperar respuesta, como única manera de reaccionar ante la nueva cachetada (Vásquez, 2011: 18).

En esta escena, la ciudad es "un estado de ánimo" (Bolaños, 1996) que representa la sugestión que Bogotá, como verdad y como motivo, ejerce sobre el tiempo del protagonista. Las palabras del narrador son indicativas no solo de hechos reales, sino, y especialmente, del clima emocional que envuelve a la capital colombiana durante los años en que el narcotráfico mostró su cara más tenebrosa. La escritura recurre a la ubicación del narrador en un momento histórico preciso para relatar la vida de una ciudad más allá de sus edificios y calles. La escenificación de los asesinatos dirigidos por los cabecillas de los carteles de la droga, se abre como pasaje para ingresar a la Bogotá de las últimas dos décadas del siglo XX, y desentrañar la relación de esta con sus habitantes. El drama humano de la sociedad colombiana, particularmente situada en la Bogotá de los noventa, se pone en escena a través de la escritura del territorio citadino: este adquiere un carácter vivo, cambiante, de acuerdo al momento histórico que lo circunscribe y la sensibilidad del personaje que lo transita.

Para Jeftanovic, la ciudad literaria es el despliegue y gravitación de todas las instancias espaciales en el texto, cuya articulación construye una estructura y un nudo semántico que habla, al mismo tiempo que los personajes, de una historia, y enuncia un discurso donde se muestra un estado de circunstancias (2007: 82). Bajo este ángulo, Bogotá en El ruido es vista entonces como un proceso en sí misma, que se construye incesantemente de los recorridos y experiencias personales de quien la ocupa y la narra. Los personajes sometidos a la violencia desatada en las calles quedan "atrapados en la espiral de la infamia que se hunde en el corazón de la urbe que habitan" (Aínsa, 2006: 161). Optar por la focalización íntima de lo cotidiano, para trazar imágenes de la vida urbana y tematizar el fenómeno del narcotráfico enfrentado a las fuerzas del sistema, ubica a Vásquez en el grupo de escritores que resitúan la relación narrativa/ciudad como red simbólica de los acontecimientos atroces de la historia reciente del país. 
El periodo nacional que El ruido escenifica se acepta como uno de los más problemáticos y decisivos en la reconfiguración de los imaginarios de nación, identidad y cultura. Numerosos estudios sobre el impacto del narcotráfico en la sociedad colombiana, reconocen que a partir de los años ochenta este fenómeno modificó considerablemente los imaginarios en torno a lo social, la estética ${ }^{4}$, lo económico, lo político, etc. Las maneras simbólicas del narcotráfico, precisa Rincón, se tomaron la sociedad latinoamericana, "habitamos en culturas en que los modos de pensar, actuar, soñar, significar y comunicar adoptan la forma narco" (2013: 2). La "narcocultura" es quizás el punto clave "de integración regional en cuanto negocio, estética, ética, experiencia de ascenso social” (p. 1).

El reconocimiento, en la novela de Vásquez, del miedo, la angustia o la indolencia de los bogotanos ante la magnitud del terrorismo del narcotráfico es indicativa de la imposibilidad del escritor latinoamericano de escapar de la relación tormentosa que la ciudad le propone. Los primeros registros de la relación del novelista latinoamericano con la ciudad -trazada por el orden colonizador- se hizo por los caminos del dolor y el desarraigo nativo, coincidiendo con el modernismo. Esto da a entender que, desde las representaciones iniciales de la ciudad moderna, el narrador latinoamericano difícilmente apuesta al mito civilizador de integración y consolidación del espacio urbano. Las narrativas que abordamos en este ensayo, proyectan, una vez más, tal perspectiva fatalista: "Nada parece detener el progresivo deterioro de las grandes capitales, amenazadas por las dramáticas contradicciones que albergan en su seno desde su propia fundación" (Aínsa, 2013: 53). Lo literario, en efecto, inscribe lo urbano en esta complejidad; la ciudad se significa como espacio de barbarie, lucha y supervivencia, faceta contraria a la idea inicial de los planificadores de la urbe como centro de civilización.

Recuérdese que la ciudad latinoamericana, en tanto idealización, se funda como civitas. La ciudad ideal, imaginada, sinónimo de civilización, no solo ordenaba la población, también buscaba preservar el

4 Juan Villoro (2009), ubicado en la sociedad mexicana, analiza la "música narco" como uno de los elementos que claramente visibiliza la influencia del narcotráfico en los cambios de los imaginarios sociales, de identidad y cultura contemporáneos. Para este ensayista, la narcocultura amplió su radio de influencia a través de los narcocorridos, muchas veces pagados por los propios protagonistas. Lo extraño, dice Villoro, es que han ganado espacio en las estaciones que transmiten música popular y aun en las antologías de literatura. El autor en su texto comenta que, en nombre de un incierto multiculturalismo, hace un par de años un grupo de escritores en 
orden, contener a sus habitantes dentro de un mapa cuyos contornos demarcados a priori pudieran someterlos en todas las formas posibles (Heffes, 2013). El diseño inicial de la ciudad, de corte feudo-burgués, y a manos del orden colonizador, constituyó un ordenamiento espacial y simbólico, que se distinguía de la exuberancia natural. El principio superior del proyecto urbanista del colono fue civilizar un territorio signado por la oscuridad y el salvajismo. En México, por caso, "lo natural incluía también al indio, la zona indígena comenzaba donde terminaba la ciudad" (Dávalos, 1991: 57). Hacia dentro del límite del territorio citadino valía un orden jurídico que favorecía las quimeras de ascenso social y enriquecimiento acelerado de los colonos. Las ciudades, analiza Rama (1998), surgieron en la inmensa extensión americana regidas por una "razón ordenadora", que se reveló en un orden jerárquico transpuesto a un orden distributivo geométrico (p. 19).

En los tiempos que corren el principio ideal de la ciudad como civitas resulta anacrónico o quimera pura, o quizás siempre lo fue. El caos inhumano, la sobrepoblación, la desigualdad social, la miseria y las múltiples violencias generadas por el choque de diversos poderes: terrorismo, discriminación, migración ilegal, narcotráfico, etc. son por antonomasia los elementos constitutivos de la ciudad sudamericana, que se agudizan con la globalización. El protagonista de El ruido, Antonio Yammara, al momento de narrar su pasado en las calles capitalinas, recuerda:

Yo tenía catorce años esa tarde de 1984 en que Pablo Escobar mató o mando a matar a su perseguidor más ilustre, el ministro de Justicia Rodrigo Lara Bonilla (dos sicarios en moto, una curva de la calle 27). Tenía dieciséis cuando Escobar mató o mandó a matar a Guillermo Cano, director de El Espectador (a pocos metros de las instalaciones del periódico, el asesino le metió ocho tiros en el pecho). Tenía diecinueve, y ya era adulto [...] cuando murió Luis Carlos Galán, candidato a la presidencia del país (Vásquez, 2011: 19).

Las vidas ficcionales, bajo estas circunstancias, resultan constituidas por lo que pasa en las plazas y avenidas capitalinas. La guerra

\footnotetext{
México protestó porque dos narcocorridos fueron suprimidos de un libro de texto. En su queja pasaron por alto que esas letras no se estudiaban en una clase sobre problemas de México, sino sobre literatura, sustituyendo a Amado Nervo o Ramón López Velarde. El narco ha contado con la anuencia de las estaciones de radio a las que amenaza o subvenciona (términos rigurosamente intercambiables) y con la empatía antropológica de quienes sobreinterpretan el delito como una forma de la tradición.
} 
desatada entre Estado y Narcotráfico, o entre los mismos carteles de la droga, para hacerse con el control del territorio, tanto a nivel geográfico como político, sucede precisamente en la nomenclatura de la urbe cotidiana. Los asesinatos que recuerda Yammara fueron practicados por sicarios en sitios puntuales de Bogotá, atentados que muchas veces arrasaron con la vida de quienes se encontraban cerca al objetivo del asesino. La memoria de la ciudad de infancia y adolescencia se alimenta de los sucesos violentos, estos se constituyen en unidad de medida del tiempo íntimo y del pasado compartido entre los habitantes de la Bogotá de esa época.

La figura del sicario es habitual en la narrativa colombiana que aborda la violencia del narcotráfico. A las ficciones que se ocupan exclusivamente de estos asesinos y de su actividad violenta Osorio (2015) las denomina "novelas del sicario" o "novelas del sicariato" (p. 15). A través de este protagonista pueden leerse las diversas violencias desencadenadas en las principales ciudades colombianas, especialmente en Medellín, urbe que fue señalada en un momento como "cuna" de sicarios. En textos icónicos como La virgen de los sicarios (1994), de Fernando Vallejo y Rosario Tijeras (1999), de Jorge Franco Ramos, se despliega la vida caótica de una Medellín asediada por la amenaza de los asesinos a sueldo. La ciudad está tan arraigada en estos libros que el escenario real parece perder fuerza frente a la intensidad metafórica como se lo representa. La Medellín de las obras de Vallejo y Franco Ramos, adaptadas también al cine, es la que pervive aún en el imaginario de muchos.

Según investigaciones sobre los miedos sociales urbanos durante las décadas de los ochenta y noventa del siglo XX, el sicario es una de las presencias que más temieron los ciudadanos de Medellín. El estudio Rostros del miedo, de Villa Martínez, Sánchez Medina y Jaramillo Arbeláez (2003), precisa que contrario a lo que sucede con el guerrillero o el paramilitar, para el habitante de la Medellín de los noventa, el sicario se constituyó en amenaza apremiante porque hacía parte del diario vivir de la ciudad. La comunidad de ese periodo percibía en este sujeto "todos los signos de destrucción" (p. 79). Por los índices elevadísimos de homicidios e inseguridad, a causa de las masacres y asesinatos selectivos que ellos ejecutaban, ordenados y pagados por los carteles de la droga, los paramilitares y otros grupos criminales, a principios de los años noventa Medellín fue conocida como una de las "ciudades más violentas del mundo".

En El olvido que seremos, Abad Faciolince refiere con detalle la realidad de la Medellín de finales de los ochenta. La narración deja ver 
la transformación de una ciudad relativamente tranquila, familiar, rezandera, en lugar del caos, de la persecución política y de la matanza. Para el autor-narrador contar la vida del padre asesinado por sicarios, es rememorar también el devenir de una ciudad, de un país, que sufría la paulatina alteración de lo cotidiano y la incubación del miedo en el seno de su sociedad:

Permanente y ávido lector de estadísticas [...] mi papá contemplaba con terror el avance progresivo de la nueva epidemia que en el año de su muerte registró cifras por homicidios más altas que las de un país en guerra [...] Ya no eran las enfermedades contra las que tanto luchó (tifoidea, enteritis, malaria, tuberculosis, polio, fiebre amarilla) las que ocupaban los primeros puestos entre las causas de muerte en el país. Las ciudades y los campos se cubrían cada vez más con la sangre de la peor de las enfermedades producidas por el hombre: la violencia. Y como los médicos de antes, que contraían la peste bubónica, o el cólera, en su desesperado esfuerzo por combatirlas, asimismo, cayó Héctor Abad Gómez, víctima de la peor epidemia, de la peste más aniquiladora que puede padecer una nación: el conflicto armado entre distintos grupos políticos, la delincuencia desquiciada, las explosiones terroristas, los ajustes de cuentas entre mafiosos y narcotraficantes (Abad Faciolince, 2006: 205).

La cita hábilmente señala uno de los descarríos más violentos que ha sufrido el país en su historia reciente. "¿Qué tipos de sociedades son estas que han de reconocerse en los espacios interrumpidos por el miedo?" (15), pregunta Susana Rotker (2000). "Ciudadanías del miedo", responde. La violencia desmesurada provoca cambios radicales en la vida y los imaginarios del sujeto citadino contemporáneo: "El cuadro de vivencias cotidianas apunta al sentimiento urbano de indefensión generalizada y al riesgo de la parálisis" (p. 16). Esta circunstancia, entre otras cosas, modifica los lugares de encuentro público. Los centros comerciales, por caso, sustituyen ahora las plazas y parques, pues solamente entre sus muros, vigilados por guardias privados, el habitante se siente seguro para deambular e interactuar con el otro. Tales espacios, enfatiza Rotker, proveen lo que las instituciones estatales han dejado de proveer: lugares civiles para el ocio y el encuentro. Las casas, asimismo, se construyen como especie de Bunker, que en su adentro dan la sensación de protección y seguridad. Parte de la identidad ciudadana de las poblaciones latinoamericanas podría definirse a partir de los nuevos espacios arquitectónicos, porque son constitutivos de lo que nos define hoy como sujetos sociales. 
El desasosiego psíquico y el sentimiento de inseguridad son rasgos comunes que identifican a los personajes en las novelas en cuestión. $\mathrm{Si}$ a principios de siglo XX, "el sentido de vivir juntos en la capital se estructuraba en torno a marcas históricas compartidas y en un espacio abarcable -en los viajes cotidianos- por todos los que la habitaban" (Canclini, 1995: 96), hoy son la desprotección, la desconfianza y el miedo los que lo caracterizan. En este orden, la ciudad literaria rige el devenir de sus habitantes, y aunque lugar propio y familiar, ya no protege. La violencia citadina que alimenta la memoria de los héroes, revela el cambio de conductas y modos de relación del colombiano consigo mismo, con el otro, el Estado y el concepto mismo de ciudadanía.

Como lugar de relación de fuerzas y espacio de manifestación del miedo, sentimientos de inseguridad y angustia, la representación anímica de la ciudad se torna estratégica en la indagación de la narrativa que incorpora las violencias más recientes del país. Los escritores, atentos a los signos vitales de la urbe, retoman la tradición literaria de reinventar los espacios urbanos y nutrirlos de disímiles imaginarios, para proponerlos como figuras simbólicas del orden social de las últimas décadas. La conciencia topográfica de la escritura reescribe los territorios citadinos como "topos del miedo", o, con más contundencia, como "geografías de la hecatombe" (Montoya, 2013), habitadas por la desolación, el dolor y el olvido.

\section{Imágenes anímicas del espacio histórico}

En las novelas de estudio la configuración de sitios urbanos particulares, figuras emblemáticas y hechos históricos, van ligadas a la faceta íntima de los protagonistas. Este tratamiento proyecta los lugares como recursos alegóricos, desde donde los significados vinculados a tales sitios pueden ser dialogados y ampliados. Si bien es cierto que la ciudad literaria, determinada por el carácter anímico de quien la narra, se aferra a la existencia de una ciudad empírica que aparece a modo de "preconcepto", no existe la intención mimética o reproductiva que se encuentra en otro tipo de discursos -documentos históricos, proyectos arquitectónicos, guías de turismo, etc. La imaginación poética se distancia de la función deíctica a la que estos apuntan. Los textos ficcionales que abordan lo urbano son "producto de la articulación de recursos literarios en función de una imagen simbólica, alternativa y no sujeta al espacio material, al que, no obstante, puede referir de manera más o menos explícita" (Locane, 2016: 71). La trama citadina en la narrativa se instala entonces como lenguaje metafórico que corrobora, discute, desplaza o amplía los sentidos de 
la ciudad empírica, no es resultado de un giro mimético, por más indicativos y realistas que sean los acontecimientos y sitios re-creados.

En Los derrotados (2012), de Pablo Montoya, la ubicación geográfica de lugares concretos, además de la precisión de las fechas exactas de cuando ocurrieron los sucesos narrados, muestra la clara intención del autor de hacer de su novela no tanto un punto de tensión o confrontación entre los espacios concretos y los textuales, entre realidad real y realidad ficcional, como sí un pasaje donde las fronteras de estas dimensiones se fusionan, complementan o diluyen. La narración literaria de hechos verídicos reconstruye el espacio, en su dimensión temporal, experiencial y simbólica, veamos:

\section{Frontino, Antioquia, noviembre de 2000}

Los dos espacios más destruidos en las guerras son la iglesia y el vientre de la mujer. El tercero es la escuela. Los soldados reconocen muy bien qué es lo que deben atacar. Todos los bandos se han ensañado contra las escuelas. Las han bombardeado, las han abaleado, las han incendiado, las han reducido a astillas porque saben el significado de ellas [...] En las fotografías de Ramírez sobre las escuelas, el centro principal es el tablero. Sobre él están los agujeros de los proyectiles o las manchas producidas por las granadas [...] En esta que veo no hay nadie [...] pero el nombre del pueblo que la rotula basta para que mi evocación de Laura Gutiérrez se imponga. Ella creía en los valores de la educación en medio de un país que lo gobiernan los representantes de la infamia. Ella podría estar ahí, en medio del tablero y las sillas, haciendo un gesto de sorpresa que grita auxilio. Pero en la fotografía no hay nadie. Los maestros y los estudiantes han terminado por convertirse en fantasmas sin voz (Montoya, 2012: 226-227).

Recuérdese que, parte de Los derrotados se apoya en fotografías genuinas de Jesús Abad Colorado 5 . "Las fotografías están fechadas [...] y se mueven de un rincón a otro de varios departamentos colombianos" (Montoya, 2012: 221). La escena anterior se corresponde con una imagen verídica. La precisión de tiempos y espacios son

5 Jesús Abad Colorado es un reconocido fotógrafo documental colombiano. Ha registrado las diversas caras del conflicto armado en Colombia. Su archivo, logrado durante dos décadas, muestra el desplazamiento forzado, el sufrimiento de las comunidades afectadas y sus actos de resistencia. Sus fotos aspiran a recuperar la memoria del pasado, crear memoria histórica como razón de un imperativo ético, que permite enfrentar los retos del presente y construir un futuro digno. 
seña común de todas las fotos que la novela incorpora. La recreación literaria de la fotografía conforma una secuencia de imágenes duales, de metáforas anfibias, en las que conviven sin repelerse lo real y lo imaginario, el presente y el pasado, la memoria y el olvido. La contigüidad narrativa entre ficción y realidad habilita a la escritura para devolver a los sucesos su elemento humano: el sufrimiento, lo emocional, que es, en definitiva, lo que lleva al lector a una comprensión íntima, personal, de la historia.

La figuración literaria de hechos históricos, espacial y temporalmente anclados a una geografía concreta, da cuenta de la inquietud de Montoya por contribuir creativamente a la construcción de la realidad del país. La versatilidad estética interviene imaginariamente en los momentos atroces de la vida de los poblados, para narrar desde adentro el miedo y el terror. Este enfoque de los lugares de la guerra los recupera para la memoria y el presente. En Los derrotados, ficción y no-ficción se interconectan para llenar el vacío que dejan los discursos oficiales sobre lo que sucede en los pueblos y campos colombianos.

Si al espacio le faltan narraciones este se pierde para siempre, afirma De Certeau (2010): "Allí donde los relatos desaparecen hay una pérdida del territorio - de la ciudad y el campo, por ejemplo-, el grupo o individuo que lo habita sufre una regresión hacia la experiencia, inquietante, fatalista, de una totalidad sin forma, indistinta, nocturna" (p. 136). Desde esta mirada, cuando las novelas citadas narran el horror de la violencia, por un lado, recobran el lugar perdido, lo proyectan sobre el dominio textual para dar coherencia y dimensión humana a los hechos, por el otro, reconstruyen una memoria nacional más justa, que incluye la vivencia traumática del habitante común. La "espacialización" del pasado y lo emocional en la ficción da cuenta de una memoria que voluntariamente o no se tiende a olvidar, transforma la historia abstracta del registro oficial en "algo que le pasa a alguien en un lugar concreto" (Vásquez, 2018: 146).

En El ruido de las cosas al caer una de las técnicas narrativas es recurrir también a la fotografía como dispositivo nemotécnico de la historia del país. Durante la búsqueda de explicación del pasado que lo marcó, el narrador consulta una serie de archivos: cartas, grabaciones, diarios y, sobre todo, fotos, que aparecen enlazados por la presencia protagónica de sitios simbólicos del poder nacional. Acá, la descripción de fotografías familiares no enfatiza tanto en las personas que aparecen en ellas, como sí en la caracterización de lugares concretos y el punto de vista personal sobre estos: 
Todo bogotano de una cierta edad tiene una foto de calle, la mayoría tomadas en la Séptima, antigua calle Real del Comercio, reina de todas las calles bogotanas; mi generación creció mirando esas fotos en los álbumes familiares, esos hombres de traje de tres piezas, esas mujeres de guantes con paraguas, gente de otra época en que Bogotá era más fría y más lluviosa y más doméstica, pero menos ardua (Vásquez, 2011: 24).

En este pasaje, Bogotá, anclada a un tiempo y espacio preciso, toma consistencia entre la percepción subjetiva de quien narra y la estructura material de los sitios. El desplazamiento y la concurrencia de los personajes en lugares públicos son prácticas que constituyen la ciudad, no solo como localidad donde se vive, sino también como lugar razonado e imaginado.

Para el personaje de Vásquez, Bogotá deja de ser algo abstracto para convertirse en una entidad cercana, íntima. A partir de este momento, las calles y demás sitios localizados conforman la materia con la que se componen el sí mismo y la memoria. La capital no es un escenario desde el que se mira transcurrir el tiempo, un objeto distante a observar, sino que forma parte de la exclusiva intimidad del narrador. Esta vivencia, Yammara la enriquece con las fotografías familiares. Son imágenes que dan forma a una red cognitiva sobre la ciudad vivida, en ellas se descifra el andar personal del protagonista por diversas zonas de Bogotá. La ciudad, espiritual y material, toma forma en la consciencia visual y topográfica de quien narra. En la mirada interpretativa de las fotografías, el narrador demuestra que ha pasado de estar maquinalmente "atrapado en las tripas del medio urbano" (Juliá, 2007: 95), a establecer una relación de descubrimiento y extrañeza con este. La emotiva descripción de las imágenes indica la consciencia de Yammara de la existencia de la ciudad.

Como recuerda Heffes (2016), desde las ideas de García Canclini (1997), "así como las ciudades están formadas por parques y casas, calles, autopistas y señales de tránsito, se encuentran a su vez formadas por imágenes" (p. 23). Están las imágenes que incluyen los mapas que se inventan y ordenan la ciudad, las que aparecen en las canciones, las películas y en los medios de comunicación. Y en el caso específico de la última cita de El ruido de las cosas al caer, están las sugestivas fotografías de tiempos pasados. "Todas estas imágenes, a su manera, imaginan y significan la vida urbana" (Heffes, 2016: 2223). A esta dialéctica de negociación, que interviene y nutre las prácticas y discursos orientados a imaginar la trama citadina, se insertan a su vez las imágenes que se producen en el espacio literario. La Bo- 
gotá textual, en derivación, funciona como recurso simbólico desde el cual se reconfiguran conocimientos vinculados a lugares de sociabilización. La capital colombiana adquiere volumen en la medida en que se va colmando de relatos, fantasías e imágenes heterogéneas.

En orden a las ideas propuestas a lo largo de este texto, podemos concluir, que las narrativas abordadas representan sitios, arquitecturas y lugares alegóricos de la experiencia particular de aquellos que los habitan, transitan o rehúyen. El rechazo de plazas y calles para la comunicación, la modificación de hábitats en campos de guerra, la estigmatización de ciertas zonas, entre otros, que la escritura significa, son gestos en los que se lee no solo la demanda de seguridad y una angustia colectiva constante, sino también la resistencia a la violencia que en ellos se manifiesta. La ciudad literaria, en este sentido, se constituye como estructura alegórica de la amenaza, su "orden caótico" se impone al personaje haciéndole recelar, temer, huir o resguardarse. Los sentimientos de angustia y miedo son parte de las fuerzas psicológicas que aproximan políticamente a las personas. Y esta aproximación se ubica en lugares y espacios precisos. Lo emocional, de esta manera, se manifiesta como motivo de mutación física y psicológica del territorio. De espacio netamente geográfico, la ciudad se transforma, en el espacio literario, en lugar político, que dice de la relación psicoafectiva del sujeto citadino contemporáneo con los lugares vividos.

\section{Bibliografía}

Abad Faciolince, H. (2006). El olvido que seremos. Bogotá: Planeta.

Aínsa, F. (2006). Del topos al logos: propuestas de geopoética. Madrid: Gedisa.

Aínsa, F. (2013). La ciudad entre la nostalgia del pasado y la visión apocalíptica. En G. Heffes. (Ed.), Utopías urbanas: geopolíticas del deseo en América Latina (pp. 49-86). Madrid y Frankfurt: Iberoamericana y Vervuert.

Bolaños, M. (1996). La ciudad es un estado de ánimo. EnEquipo IVAM. La ciudad en la colección del IVAM (pp. 9-19) Valencia: I.V.A.M.

Calvino, I. (1985). Las ciudades invisibles. Barcelona: Minotauro.

Dávalos, M. (1991). La traza: origen mítico de la ciudad. Historias, (27), 57-61. 
Ferrero, G. (2013). El poder. Los genios invisibles de la ciudad. Madrid: Tecnos.

García Canclini, N. (1995). Consumidores y ciudadanos. México: Grijalbo.

García Canclini, N. (1997). Imaginarios urbanos. Buenos Aires: Editorial Universitaria de Buenos Aires.

Giraldo, L. M. (2001). Ciudades escritas. Literatura y ciudad en la narrativa colombiana. Bogotá: Andrés Bello.

Giraldo, L. M. y Gómez, B. I. (2011). Testimonios representaciones y literatura documental en la narrativa colombiana contemporánea 1970-2004. En J. A. Rodríguez. (Ed.), Hallazgos en la literatura colombiana. Balance y proyección de una década de investigaciones (pp.15-28). Bogotá: Pontificia universidad Javeriana.

Heffes, G. (Ed.). (2013). Utopías Urbanas: geopolíticas del deseo en América Latina. Madrid y Frankfurt: Iberoamericana y Vervuert.

Jeftanovic, A. (2007). Mapocho de Nona Fernández: la ciudad entre la colonización y la globalización. Chasqui, 36( 2), 73-84.

Juliá, P. (2007). La ciudad como objeto fotográfico. Revista Litoral, (244), 94-99.

Lefebvre, H. (1968). Le Droit à la ville. Paris: Anthropos.

Locane, J. (2016). Miradas locales en tiempos globales. Intervenciones literarias sobre la ciudad latinoamericana. Madrid y Frankfurt: Iberoamericana y Vervuert.

Martín-Barbero, J. (2000). La ciudad: entre medios y miedos. En S. Rotker (Ed.). Ciudadanías del miedo (pp. 29-35). Caracas: Nueva Sociedad.

Montoya, P. (2013). Retratos de un país invisible: fotografías de Jorge Mario Múnera. Recuperado de http://www.pablomontoya. net/retratos-de-un-pais-invisible-fotografias-de-jorge-mario-munera/

Montoya, P. (2012). Los derrotados. Medellín: Sílaba. 
Rama, Á. (1998). La ciudad Letrada. Montevideo: Arca.

Rincón, O. (2013). Todos llevamos un narco adentro -un ensayo sobre la narco/cultura/telenovela como modo de entrada a la modernidad. Matrizes, 7(2), 01-33.

Rotker, S. (Ed.). (2000). Ciudadanías del miedo. Caracas: Nueva Sociedad.

Vásquez, J. G. (2011). El ruido de las cosas al caer. Bogotá: Alfaguara.

Villa Martínez, M. I., Sánchez Medina, L. A. y Jaramillo Arbeláez, A. M. (2003). Rostros del miedo. Una investigación sobre los miedos sociales urbanos. Medellín: Corporación Región.

Villoro, J. (2009). La alfombra roja. El imperio del narcoterrorismo. Revista N. Buenos Aires: Clarín. 